\title{
Assessment of beef carcass contamination with Salmonella and E. coli O 157 in slaughterhouses in Bishoftu, Ethiopia
}

Fanta D. Gutema ${ }^{1,2^{*}}$ D, Reta D. Abdi ${ }^{3}$, Getahun E. Agga ${ }^{4}$, Seyoum Firew ${ }^{1}$, Geertrui Rasschaert ${ }^{5}$, Wesley Mattheus ${ }^{6}$, Florence Crombe ${ }^{7}$, Luc Duchateau ${ }^{8}$, Sarah Gabriël ${ }^{2}$ and Lieven De Zutter $^{2}$

\begin{abstract}
Background: Salmonella and E. coli $\mathrm{O} 157$ are common causes of foodborne diseases. Evisceration and de-hiding steps can lead to carcass contamination during slaughter operation. In Ethiopia, information on the association between the presence of these pathogens in the rectal content and/or on the hide of cattle and their presence on the carcass is lacking.

Methods: The aim of this study was to assess the sources of beef carcass contamination with Salmonella and E. coli O157 during slaughter. Rectal contents and hide- and carcass-swabs (from three sites: foreleg, brisket and hind leg) were collected from 70 beef cattle at two small scale slaughterhouses. Isolates were genotyped by the Pulsed Field Gel Electrophoresis method and tested for resistance against 14 microbial drugs.

Results: Salmonella was detected at equal proportions (7.1\%) in rectal content samples and hide swabs. E. coli O157 was detected in $8.6 \%$ of the rectal contents and $4.3 \%$ of the hide swabs. The proportion of contaminated carcasses was $8.6 \%$ for Salmonella and 7.1\% for E. coli 0157. Genetic linkage between the Salmonella and E. coli 0157 isolates from the rectal contents and/or hides and carcasses were observed only in a few cases ( 2 and 1 carcasses, respectively) indicating the limited direct transfer of the pathogens from the feces and/or hide to the carcass during slaughter. Most carcasses became positive by cross contamination. All the S. Typhimurium isolates $(n=8)$ were multidrug resistant being resistant to ampicillin, chloramphenicol, sulfamethoxazole and tetracycline. The two S. Dublin isolates were resistant to colistin. All E. coli O157 isolates were susceptible to the antimicrobials tested.
\end{abstract}

Conclusion: The results indicated that cross contamination may be an important source for carcass contamination. Keywords: Salmonella, Escherichia coli O157, Slaughterhouse, Beef carcass, Contamination, Rectal content, Hide

\footnotetext{
* Correspondence: fantadesissa@gmail.com

${ }^{1}$ Department of Microbiology, Immunology and Veterinary Public Health,

College of Veterinary Medicine and Agriculture, Addis Ababa University, P. O. Box 34, Bishoftu, Ethiopia

${ }^{2}$ Department of Veterinary Public Health and Food Safety, Faculty of Veterinary Medicine, Ghent University, 9820 Merelbeke, Belgium

Full list of author information is available at the end of the article
}

(C) The Author(s). 2021 Open Access This article is licensed under a Creative Commons Attribution 4.0 International License, which permits use, sharing, adaptation, distribution and reproduction in any medium or format, as long as you give appropriate credit to the original author(s) and the source, provide a link to the Creative Commons licence, and indicate if changes were made. The images or other third party material in this article are included in the article's Creative Commons. licence, unless indicated otherwise in a credit line to the material. If material is not included in the article's Creative Commons licence and your intended use is not permitted by statutory regulation or exceeds the permitted use, you will need to obtain permission directly from the copyright holder. To view a copy of this licence, visit http://creativecommons.org/licenses/by/4.0/ The Creative Commons Public Domain Dedication waiver (http://creativecommons.org/publicdomain/zero/1.0/) applies to the data made available in this article, unless otherwise stated in a credit line to the data. 


\section{Introduction}

Foodborne diseases (FBD) are a worldwide problem. Consumption of contaminated food of animal origin is associated with potential food safety risks and a major source of FBD. Salmonella and Shiga toxin-producing $E$. coli are major causes of FBD (Havelaar et al. 2015). Ruminants, particularly cattle, are reservoirs and asymptomatic carriers of Salmonella (Cummings et al. 2010; Gutema et al. 2019) and E. coli O157 (Gyles 2007). Studies reported the occurrence of these pathogens in the feces and on the hides of cattle on farms and in slaughterhouses in developed countries (Arthur et al. 2010; Cobbaut et al. 2008; Essendoubi et al. 2019; Madoroba et al. 2016). The presence of Salmonella and E. coli O157 in the feces and on the hides of cattle may lead to their transfer to carcasses during hide removal and evisceration (Croxen et al. 2013; Cummings et al. 2010; Gutema et al. 2021a).

Consumption of contaminated beef and beef products is one of the transmission routes of Salmonella and E. coli O157 to humans (EFSA and ECDC 2018; Pires et al. 2019) and has been implicated in many foodborne outbreaks (CDC 2016; Plumb et al. 2019). This is particularly important in countries like Ethiopia where consumption of raw or under-cooked beef in the form of steak ("kurt") or beef tartare ("kitfo") made from raw minced beef, is common (Avery 2014; Seleshe et al. 2014). Consumption of raw beef products can be a source of Salmonella and E. coli O157 infections in Ethiopia (Gutema et al. 2021b, c).

In Ethiopia, few studies have reported the prevalence of Salmonella in cattle feces (Gutema et al. 2021c; Takele et al. 2018), on hides (Sibhat et al. 2011) and on carcasses (Atsbha et al. 2018; Takele et al. 2018). Similarly, E. coli O157 was reported in cattle feces (Abdissa et al. 2017; Gutema et al. 2021b; Haile et al. 2017), on hides (Abdissa et al. 2017) and on carcasses (Atnafie et al. 2017) at the slaughterhouse level. We previously identified dehiding and evisceration as two major potential sources of carcass contamination at slaughterhouses in Ethiopia (Gutema et al. 2021a). However, there is currently no data confirming the potential association between the presence of these pathogens in the rectal content and/or on the hide of cattle and their presence on the carcass. Determining the genetic relatedness of Salmonella and E. coli 0157 in cattle feces, on the hide and on the carcass is essential to investigate the potential transfer to carcasses. This will also contribute to the identification of critical control points and the development of mitigation strategies to ensure beef safety.

The objective of this study was to investigate the occurrence and the genetic relatedness for both Salmonella and E. coli $\mathrm{O} 157$ isolated from the rectal content and hide, and the carcass at slaughterhouses. Antimicrobial resistance of Salmonella and E. coli O157 isolates obtained from rectal contents, hides and carcass was further assessed.

\section{Materials and methods Slaughterhouses}

The study was conducted from November 2018 to May 2019 at two slaughterhouses in Bishoftu town located in East Shoa Zone, Oromia, Ethiopia. Both slaughterhouses were small in process capacity whereby the municipal slaughterhouse and the private slaughterhouse usually slaughtered 5-15 and 15-30 cattle per day, respectively. The retail shop owners buy cattle from open markets and bring them to the slaughterhouse for slaughter service. The slaughter process at both slaughterhouses was rather similar. Briefly, the manual slaughter process involved stunning with a sharp knife, bleeding by cutting arteries and veins in the throat region, removal of head and feet and dehiding the upper part of the hind legs on the floor followed by hanging of the carcass, manual dehiding, evisceration, carcass washing, post-mortem inspection, carcass labelling and storage at environmental temperature until distribution to retail shops. The slaughterhouses did not have a stand-by pressurized water supply and hot water for hand and equipment including knives washing. Moreover, slaughterhouse workers were involved in different slaughter steps and received no or limited hygienic training (Gutema et al. 2021a).

\section{Sample collection}

Samples were collected from 70 animals (35 in each slaughterhouse). Seven visits per slaughterhouse were organized whereby each time, 5 carcasses were sampled during slaughter. Due to the presence of relatively many cattle in the lairage of the private slaughterhouse, animals were selected using systematic random sampling before slaughter whereas at the municipal slaughterhouse due to the limited number of animals present in the lairage, five consecutively slaughtered animals slaughtered the day of sampling were sampled. The following samples were collected from each carcass: one rectal content $(50 \mathrm{~g})$, one hide and three carcass swab samples. The hide swab was taken from the medial side of the foreleg and hind leg and the brisket from one half of the carcass immediately after stunning. From each hide swabbing site, an area of $20 \times 20 \mathrm{~cm}$ was swabbed using the same sterile cotton swab pre-moistened in 10 $\mathrm{ml}$ buffered peptone water (BPW; Difco, BD, Sparks, MD, USA). Separate carcass swabs $(20 \times 20 \mathrm{~cm})$ per site were obtained after evisceration and before washing from the same sites as the hide swabs, but on the other half of the carcass. Samples were transported in an 
icebox to the laboratory and stored at $4{ }^{\circ} \mathrm{C}$ until processing within $24 \mathrm{~h}$.

\section{Detection of Salmonella and E. coli 0157}

For processing of the hide and carcass swabs, each swab in $10 \mathrm{ml} \mathrm{BPW}$ was transferred into a stomacher bag containing another $30 \mathrm{ml} \mathrm{BPW}$ to make a final volume of $40 \mathrm{ml}$ and homogenized for $2 \mathrm{~min}$ using a stomacher. From the final volume of homogenized solution, $20 \mathrm{ml}$ was transferred into another stomacher bag.

Salmonella detection was based on the International Organization for Standardization guideline ISO 6579-1: 2017 (ISO 2017). Briefly, $25 \mathrm{~g}$ of rectal content was transferred into a sterile stomacher bag, $225 \mathrm{ml}$ of BPW was added and the mixture was homogenized using a stomacher blender for $1 \mathrm{~min}$ at $200 \mathrm{rpm}$. Homogenized rectal content, hide and carcass swabs were incubated at $37^{\circ} \mathrm{C}$ for $18 \mathrm{~h}$. After the incubation of the preenrichment broths, $0.1 \mathrm{ml}$ of each culture medium was spotted in 3 drops onto a modified semi solid Rappaport-Vassiliadis medium (MSRV; Oxoid, Basingstoke, UK) and incubated at $41.5^{\circ} \mathrm{C}$ for $24 \mathrm{~h}$. After incubation, plates were examined for the presence of migration zones. A loopful from the edge of a migration zone was streaked onto xylose lysine deoxycholate (XLD, Difco) agar plates and incubated at $37^{\circ} \mathrm{C}$ for $24 \mathrm{~h}$. Plates were examined for the presence of suspect Salmonella colonies. Suspected colonies were biochemically tested using triple sugar iron agar slants (Difco, BD), lysine decarboxylase test (BBL, BD), and indole test (BBL, BD). One confirmed isolate per sample was stored at $-18^{\circ} \mathrm{C}$ for further characterization. Collected Salmonella isolates were subjected to a $S$. Typhimurium PCR using the primers described by Lin et al. (1999). All isolates negative for this PCR were then clustered using enterobacterial repetitive intergenic consensus (ERIC) PCR as described by Rasschaert et al. (2005). Based on the data obtained from each ERIC profile at least one isolate was selected for serotyping according to the KauffmannWhite scheme (Grimont and Weill 2007) at Belgian National Reference Laboratory for Salmonella.

E. coli O157 detection was based on International Organization for Standardization, horizontal method for the detection of E. coli O157-ISO 16654: 2001 (ISO 2001). Twenty-five gram of each rectal content sample was transferred into a stomacher bag containing $225 \mathrm{ml}$ of modified tryptone soya broth (Oxoid) supplemented with $20 \mathrm{mg} / \mathrm{l}$ novobiocin (Sigma Aldrich, MO; USA) (mTSBn), homogenized using a stomacher blender for 1 $\mathrm{min}$ at $200 \mathrm{rpm}$. For the detection of E. coli $\mathrm{O} 157$ from the swab samples, $20 \mathrm{ml}$ double concentrated mTSBn was added to stomacher bags containing $20 \mathrm{ml}$ of the sample homogenate. After the incubation of the enrichment broths at $41.5^{\circ} \mathrm{C}$ for $6 \mathrm{~h}, 1 \mathrm{ml}$ of each broth was manually subjected to immunomagnetic separation (IMS) using Dynabeads anti-E. coli O157 (ThermoFisher Scientific, West Palm Beach, FL, USA) according to the manufacturers' instruction. The final washed beadbacteria complexes were spread onto cefixime tellurite sorbitol MacConkey agar plates (Oxoid) containing 0.05 $\mathrm{mg} / \mathrm{l}$ cefixime and $2.5 \mathrm{mg} / 1$ potassium tellurite (Oxoid) (CT-SMAC). After incubation at $37^{\circ} \mathrm{C}$ for $24 \mathrm{~h}$, the plates were examined for the presence of suspect colonies. From each selective agar plate, up to three suspect colonies were subjected to Kligler Iron agar, indole and E. coli $\mathrm{O} 157$ latex agglutination (Oxoid) tests. In the frame of another research project, one isolate per positive sample was further analyzed using whole genome sequencing method described by De Rauw et al. (2019) at the Belgian National Reference Center for STEC. Data on the presence of $s t x$ genes, eae gene, and $e h x A$ gene in those isolates was obtained from this analysis.

\section{Pulsed field gel electrophoresis (PFGE)}

Both Salmonella and E. coli O157 isolates (one isolate per positive sample) were genotyped by PFGE after digestion with $\mathrm{XbaI}$ enzyme (CDC 2017). The fingerprints were grouped according to their similarity with Bionumerics 7.6 software (Applied Maths, Biomérieux, SintMartens-Latem, Belgium) using the band-based dice coefficient with a $2 \%$ position tolerance and unweightedpair group method using arithmetic averages (UPGMA). Pulsotypes were assigned based on the difference of at least one band in the fingerprints and indicated by capital letter.

\section{Antimicrobial susceptibility testing}

All Salmonella and E. coli $\mathrm{O} 157$ isolates were tested for their antimicrobial resistance to the following 14 antimicrobial drugs with tested concentration range $(\mu \mathrm{g} / \mathrm{ml})$ in brackets: ampicillin (1-64), azithromycin (2-64), cefotaxime (0.25-4), ceftazidime (0.5-8), chloramphenicol (8-128), ciprofloxacin (0.015-8), colistin (1-16), gentamicin (0.5-32), meropenem (0.03-16), nalidixic acid (4128), sulfamethoxazole (8-1024), tetracycline (2-64), tigecycline (0.25-8) and trimethoprim (0.25-32). The resistance profiling was evaluated based on the minimum inhibitory concentration (MIC) using Sensititre EU surveillance Salmonella/E. coli (EUVSEC) plates (Thermo Fisher Scientific, Merelbeke, Belgium). The tests were performed according to the manufacturer's instructions. The standard reference strain E. coli ATCC 25922 was used as quality control. European Committee on Antimicrobial Susceptibility Testing (EUCAST) epidemiological breakpoint values were used to categorize the isolates as resistant or susceptible. In case of Salmonella, for sulfamethoxazole, tigecycline and colistin the 
epidemiological breakpoints for $E$. coli were used (EUCAST 2019).

\section{Results}

From the 70 cattle examined, 23 (32.9\%) were positive for Salmonella and/or E. coli $\mathrm{O} 157$ in at least one sample. Specifically, $14(20.0 \%)$ animals were positive for Salmonella, and 11 (15.7\%) for E. coli O157 (Table 1). Two animals were positive for both Salmonella and $E$. coli O157 (Table 2).

\section{Salmonella}

From the 14 Salmonella positive carcasses, the following 16 samples were positive: 5 rectal contents $(7.1 \%), 5$ hides (7.1\%) and 6 carcasses (1 foreleg, 2 briskets and 3 hind legs) (8.6\%). Only in two cases, two samples of the same animal were positive: the rectal content and the carcass (brisket) from one animal, and the rectal content and the carcass (hind leg) from the other animal. The 16 Salmonella isolates were identified as $S$. Chailey, $S$. Dublin, $S$. Muenchen and $S$. Typhimurium. All isolates within a serotype belonged to a single pulsotype (Fig. 1). The isolates from the animals with two positive samples were identified as $S$. Typhimurium. The supplementary Table 1 shows the MIC distributions of the Salmonella isolates. All $S$. Typhimurium isolates showed the same resistance profile, namely resistant to ampicillin, chloramphenicol, sulfamethoxazole and tetracycline, while the two $S$. Dublin isolates were only resistant to colistin. Salmonella Chailey and $S$. Muenchen were sensitive to all 14 antimicrobial drugs tested.

\section{E. coli 0157}

Of the 11 E. coli $\mathrm{O} 157$ positive carcasses, the following 14 samples were positive: 6 rectal contents (8.6\%), 3 hides (4.3\%) and 5 carcasses ( 1 foreleg, 2 briskets and 2 hind legs) (7.1\%). In three cases, two samples of the same animal were positive for E. coli O157: hide and carcass (hind leg), rectal content and hide, and rectal content and carcass (hind leg). E. coli O157 isolates were grouped into eight pulsotypes (A-I) (Fig. 2). Among the isolates obtained from the same animals $(n=3)$, genetic relatedness was observed only between isolates obtained from a hide and a carcass (hind leg) swab of one animal sampled at the municipal slaughterhouse. All the E. coli O157 isolates carried the eae and the $e h x A$ gene; the st $x 2$ gene (10 stx $2 \mathrm{c}$ and 2 stx $2 \mathrm{a}$ ) was detected in $85.7 \%$ $(12 / 14)$ of the isolates while the $s t x 1$ gene was not detected in any of the isolates. The stx2a subtypes were detected in isolates from a brisket and a hide swab. All $E$. coli $\mathrm{O} 157$ isolates were sensitive to the 14 antimicrobial drugs tested.

\section{Discussion}

The present study detected for the first time in Ethiopia Salmonella and E. coli $\mathrm{O} 157$ in the rectal content, on the hide and on cattle carcass at slaughterhouses. Although Salmonella was detected at the same proportion (7.1\%) of the feces and the hide swabs, it was not simultaneously detected from the same carcasses. The proportion of positive rectal contents was comparable with the national prevalence estimate of $7.1 \%$ (variation from $2.1 \%$ to $16.2 \%$ ) in Ethiopia (Tadesse and Tessema 2014) but lower than the pooled prevalence estimate of $15.4 \%$ with a variation from 11.7 to $20 \%$ in Africa (Thomas et al. 2020). The proportion of Salmonella positive hide samples was lower compared to a study by Sibhat et al. (2011) who reported a prevalence of $31 \%$ in Ethiopia. Studies that have been conducted elsewhere indicated the occurrence of Salmonella on hides of cattle at slaughterhouses with a variable prevalence ranging from $17.7 \%$ in England (Reid et al. 2002) and up to $94 \%$ in USA (Brichta-Harhay et al. 2008).

The proportion of E. coli $\mathrm{O} 157$ in rectal contents and on hides was 8.6 and $4.3 \%$, respectively. The proportion of positive rectal contents was slightly higher compared to global prevalence estimate of $5.7 \%$ that ranges from $0.1 \%$ to $61.8 \%$ (Islam et al. 2014). A recent study by

Table 1 Proportion of Salmonella and E. coli 0157 in the rectal content, hide and carcass swabs obtained from 70 beef cattle in Bishoftu, Ethiopia

\begin{tabular}{|c|c|c|c|c|}
\hline \multirow[t]{2}{*}{ Source } & \multirow[t]{2}{*}{ Number of samples } & \multicolumn{2}{|l|}{ Salmonella } & \multirow{2}{*}{$\begin{array}{l}\text { E. coli } 0157 \\
\text { Number (\%) }\end{array}$} \\
\hline & & Number (\%) & Serotypes & \\
\hline Rectal content & 70 & $5(7.1)$ & Typhimurium (5) & $6(8.6)$ \\
\hline Hide & 70 & $5(7.1)$ & Typhimurium (1), Dublin (1), Chailey (2), Muenchen (1) & $3(4.3)$ \\
\hline Carcass & 210 & $6(8.6)$ & & $5(7.1)$ \\
\hline Fore leg & 70 & $1(1.4)$ & Dublin (1) & $1(1.4)$ \\
\hline Hind leg & 70 & $3(4.3)$ & Typhimurium (1), Chailey (1), Muenchen (1) & $2(2.8)$ \\
\hline Brisket & 70 & $2(2.8)$ & Typhimurium (1), Muenchen (1) & $2(2.8)$ \\
\hline Total & 350 & 16 & & 14 \\
\hline Animal & & $14(20.0)$ & & $11(15.7)$ \\
\hline
\end{tabular}


Table 2 Distribution of Salmonella and E. coli 0157 isolates among the positive cattle identified at two slaughterhouses in Bishoftu, Ethiopia

\begin{tabular}{|c|c|c|c|c|c|c|c|}
\hline \multirow{3}{*}{ Slaughterhouse } & \multirow{3}{*}{ Visit } & \multirow{3}{*}{$\underset{\text { Animal* }}{\text { AD }}$} & \multicolumn{5}{|c|}{ Sample type } \\
\hline & & & \multirow{2}{*}{$\begin{array}{l}\text { Rectal } \\
\text { content }\end{array}$} & \multirow{2}{*}{ Hide } & \multicolumn{3}{|c|}{ Carcass swabs } \\
\hline & & & & & Foreleg & Brisket & Hind leg \\
\hline \multirow[t]{10}{*}{ Municipal } & B & 1 & + & + & - & + & + \\
\hline & $\mathrm{B}$ & 5 & + & - & - & - & - \\
\hline & $\mathrm{C}$ & 3 & + & - & - & - & - \\
\hline & $\mathrm{D}$ & 3 & - & + & - & - & - \\
\hline & $\mathrm{D}$ & 4 & + & - & - & - & + \\
\hline & $\mathrm{E}$ & 2 & - & + & - & - & - \\
\hline & $\mathrm{E}$ & 5 & + & - & - & - & - \\
\hline & $\mathrm{F}$ & 3 & + & - & - & - & - \\
\hline & $\mathrm{F}$ & 4 & - & - & - & - & + \\
\hline & $\mathrm{G}$ & 3 & - & - & - & + & - \\
\hline \multirow[t]{13}{*}{ Private } & $\mathrm{A}$ & 2 & + & + & - & - & - \\
\hline & $\mathrm{A}$ & 3 & - & - & + & - & - \\
\hline & $\mathrm{C}$ & 4 & + & - & - & + & - \\
\hline & $\mathrm{D}$ & 1 & - & - & - & - & + \\
\hline & $\mathrm{D}$ & 2 & + & - & - & - & - \\
\hline & $\mathrm{D}$ & 3 & - & + & - & - & - \\
\hline & $\mathrm{D}$ & 4 & - & + & - & - & - \\
\hline & $\mathrm{D}$ & 5 & - & + & - & - & - \\
\hline & $\mathrm{E}$ & 1 & + & - & - & - & - \\
\hline & $\mathrm{E}$ & 5 & + & - & - & - & - \\
\hline & $\mathrm{F}$ & 2 & - & - & - & + & - \\
\hline & $\mathrm{F}$ & 5 & - & - & - & - & + \\
\hline & $\mathrm{G}$ & 3 & - & + & + & - & - \\
\hline
\end{tabular}

+Sample positive for Salmonella; + Sample positive for E. coli 0157

identification number of each animal/visit

Gutema et al. (2021b) reported $7.1 \%$ positive rectal contents collected from cattle in the lairage at the same slaughterhouses. The $4.3 \%$ positive hides was lower compared to the global prevalence estimate of $44 \%$ with a variation from 7.3 to $76 \%$ (Rhoades et al. 2009). Only from one carcass, E. coli $\mathrm{O} 157$ was detected from the rectal content and the hide concomitantly. However, genetic typing showed that the isolates from both samples were not identical, indicating that the feces of the animal was not the source of the hide contamination.

In the present study, we observed a carcass contamination rate of 8.6 and $7.1 \%$ for Salmonella and E. coli O157, respectively. The carcass contamination with Salmonella was comparable to the prevalence of $7.6 \%$ (Muluneh and Kibret 2015), 12.5\% (Wabeto et al. 2017) and 11.3\% (Takele et al. 2018) in Ethiopia. For E. coli O157 variable proportions of carcass contamination were reported: from $0.54 \%$ by Abdissa et al. (2017) up to $13.3 \%$ by Bekele et al. (2014) for Ethiopia. For both pathogens, positive carcasses were only found positive on one carcass site, indicating that the carcass contamination is in most cases not widespread over the positive carcasses. As a consequence, collecting swab samples from multiple sites on a carcass may increase the number of positive carcasses. According to the EU regulation 2073/2005 beef carcasses sampled for bacteriological analysis, four carcass sites have to be swabbed (European Commission 2005). However, such regulation is not available for Ethiopia. Thus, it is essential to include adequate number of carcass sites to be sampled for 


\begin{tabular}{|c|c|c|c|c|}
\hline \multirow{17}{*}{ F. } & $\begin{array}{l}\text { Sample } \\
\text { code }^{\circ}\end{array}$ & Serotype & Pulsotype & $\begin{array}{l}\text { Resistance } \\
\text { Profile }^{\circ 0}\end{array}$ \\
\hline & $\mathrm{PD} 3 \mathrm{H}$ & S. Dublin & A & $\mathrm{COL}$ \\
\hline & PA3Fo & S. Dublin & A & $\mathrm{COL}$ \\
\hline & $\mathrm{PD} 4 \mathrm{H}$ & S. Chailey & B & $s$ \\
\hline & PD1HI & S. Chailey & B & s \\
\hline & PD5H & S. Chailey & B & S \\
\hline & $\mathrm{MB} 1 \mathrm{Br}$ * & S. Typhimurium & C & AMP-CHL-SMX-TET \\
\hline & MD4HI ** & S. Typhimurium & c & AMP-CHL-SMX-TET \\
\hline & PE5R & S. Typhimurium & c & AMP-CHL-SMX-TET \\
\hline & PG3H & S. Typhimurium & C & AMP-CHL-SMX-TET \\
\hline & MC3R & S. Typhimurium & c & AMP-CHL-SMX-TET \\
\hline & MD4R * & S. Typhimurium & c & AMP-CHL-SMX-TET \\
\hline & ME5R & S. Typhimurium & c & AMP-CHL-SMX-TET \\
\hline & MB1R * & S. Typhimurium & C & AMP-CHL-SMX-TET \\
\hline & PF5HI & S. Muenchen & $\mathrm{D}$ & $s$ \\
\hline & $\mathrm{MG} 3 \mathrm{Br}$ & S. Muenchen & D & $\mathrm{s}$ \\
\hline & ME2H & S. Muenchen & $D$ & s \\
\hline $\begin{array}{l}\text { Fig. } 1 \text { Pulsed-f } \\
\text { Bishoftu, Ethior } \\
\text { to 5), last letter } \\
\text { ampicillin; CHL } \\
\text { same carcass }\end{array}$ & $\begin{array}{l}\text { onella isolat } \\
\text { stter - samp } \\
\text { racycline. * }\end{array}$ & $\begin{array}{l}\text { om rectal cont } \\
\text { visit (A to G); } n \\
\text { arcass, Fo: forel } \\
\text { tes from a sam }\end{array}$ & $\begin{array}{l}\text { ts, hides and } \\
\text { mber - carcas } \\
\text { carcass). }{ }^{\circ} \\
\text { carcass. }^{* *} \text { Is }\end{array}$ & $\begin{array}{l}\text { vef carcasses in } \\
\text { vithin each visit (1 } \\
\text { usceptible; AMP- } \\
\text { tes from a }\end{array}$ \\
\hline
\end{tabular}

bacteriological analysis in the beef safety regulation of Ethiopia.

Only in a few cases Salmonella or E. coli O157 were detected simultaneously in the rectal content or on the hide, and on the corresponding carcasses. For the two Salmonella isolates and one of the three E. coli $\mathrm{O} 157$ isolates, respectively from the rectal content and hide, and the carcass swabs were genetically similar, indicating a possible direct transfer of the pathogen to the carcass surface. In all other cases, no genetic link was stated between isolates from the rectal content and/or hide isolates and the carcass swabs. The observed low level of linkage of Salmonella and E. coli O157 isolates on carcass with those from rectal contents and/ or hide indicates that other sources may be involved in the carcass contamination during slaughter. This could be due to cross contamination caused by unhygienic handling practices such as infrequent washing of knifes and hands

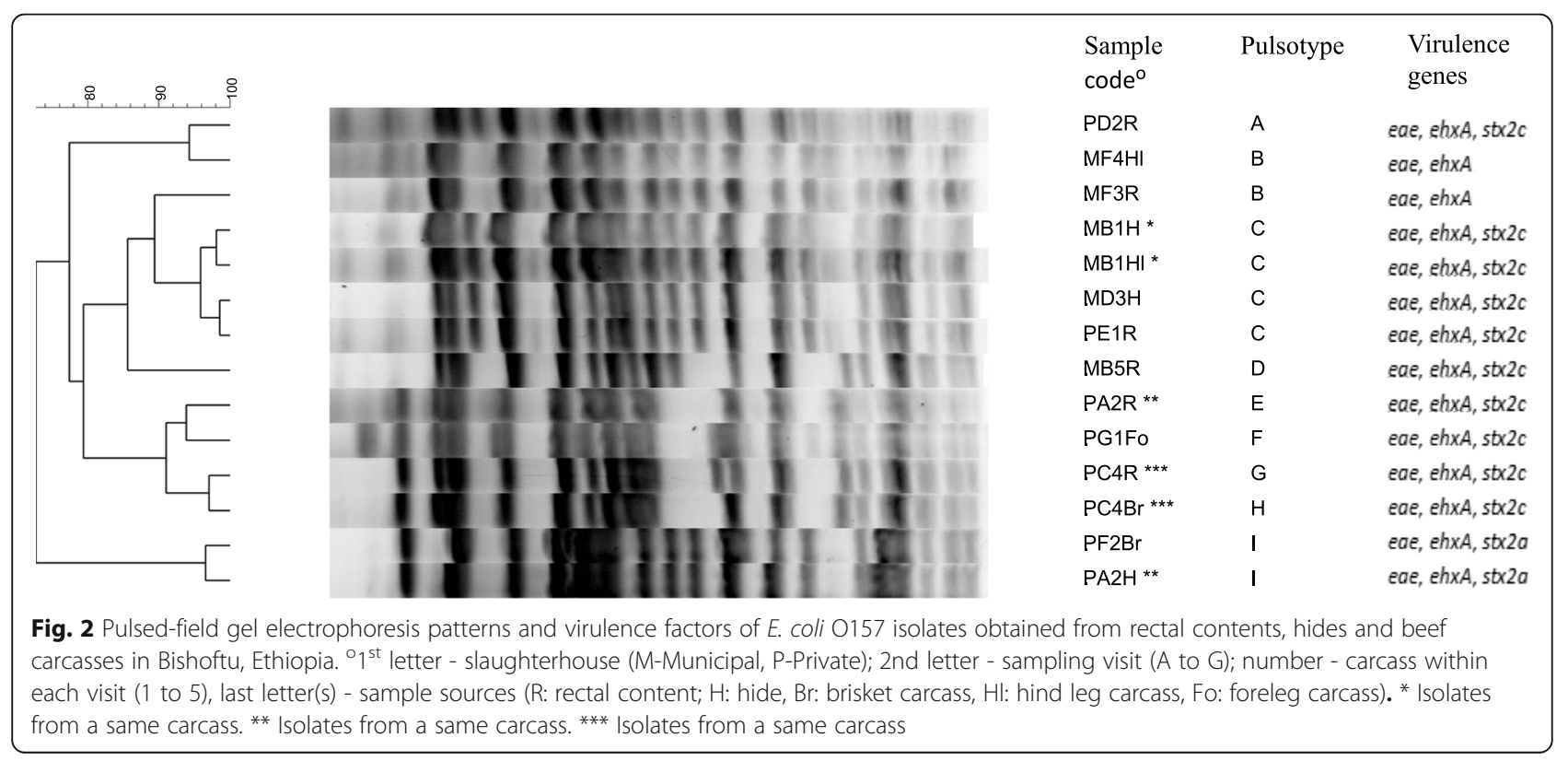


(Gutema et al. 2021a). Contamination and cross contamination of hides during cattle transport or in the lairage could increase the risk of carcass contamination.

Salmonella Dublin was isolated from the hide of one carcass and from the foreleg of another carcass in this study and it was also previously reported from retail beef in Ethiopia (Ejeta et al. 2004) indicating that this serotype is present in the cattle population and can be a source for human infections. S. Dublin is known to cause invasive infections and fatalities in humans (Harvey et al. 2017; Mattheus et al. 2018). In Ethiopia, $S$. Dublin was sporadically reported from stool of diarrheic patients (Tadesse 2014).

All $S$. Typhimurium isolates were multidrug resistant being resistant to ampicillin, chloramphenicol, sulfamethoxazole and tetracycline. Except for chloramphenicol, similar resistance profile was observed for $S$. Typhimurium isolates from cattle before slaughter at the same slaughterhouses (Gutema et al. 2021c). This suggests the widespread occurrence of ampicillin, sulfonamides and tetracycline resistance in $S$. Typhimurium isolated from cattle in Ethiopia and may be related to the long-time marketing and accessibility of these drugs. The two $S$. Dublin isolates were resistant to colistin. Resistance to this antibiotic seems to be common in $S$. Dublin isolates (EFSA and ECDC 2020). The finding that all 14 E. coli $\mathrm{O} 157$ isolates being susceptible to the 14 antimicrobials tested was in agreement with our previous study that have reported susceptibility of E. coli $\mathrm{O} 157$ isolates except one isolate obtained from beef in the study area (Gutema et al. 2021a).

\section{Conclusions}

During slaughter, beef carcasses can become contaminated with Salmonella and/or E. coli 0157. The contamination was not widespread over positive carcasses. The study indicated the frequent occurrence of cross contamination besides the direct contamination of carcasses by feces and hide of positive animals. More studies are needed to unravel the sources for this cross contamination and to develop efficient preventive measures to ensure beef safety.

\footnotetext{
Abbreviations

BPW: Buffered Peptone Water; CT-SMAC: Cefixime Tellurite Sorbitol MacConkey Agar; ERIC: Enterobacterial Repetitive Intergenic Consensus; EUCAST: European Committee on Antimicrobial Susceptibility Testing; EUVSEC: Sensititre European Union Surveillance Salmonella/E.coli; FBD: Foodborne diseases; IMS: Immunomagnetic Separation; MIC: Minimum inhibitory concentration; MSRV: Modified Semi Solid Rappaport-Vassiliadis Medium; mTSBn: Modified Tryptone Soya Broth supplemented with novobiocin; PFGE: Pulsed Field Gel Electrophoresis; XLD: Xylose Lysine Deoxycholate; UPGMA: Unweighted-pair group method using arithmetic averages
}

\section{Supplementary Information}

The online version contains supplementary material available at https://doi. org/10.1186/s40550-021-00082-1.

Additional file 1 : Supplementary Table 1. Distribution of the minimum inhibitory concentrations (MICs) of Salmonella isolates obtained from rectal contents $(n=5)$, hide swabs $(n=5)$ and carcasses $(n=6)$ in Bishoftu town, Ethiopia

\section{Acknowledgments}

We thank Tsedale Teshome, Sjarlotte Willems and Eline Dumoleijn for technical support. Mention of trade names or commercial products by USDA author (GEA) in this publication is solely for the purpose of providing specific information and does not imply recommendation or endorsement by the U.S. Department of Agriculture. USDA is an equal opportunity provider and employer.

\section{Authors' contributions}

All the authors made significant contributions to the manuscript and agree to its publication. The contributions were performed in the following order: Conceived and designed the study: FDG, RDA, GEA, LD, SG, LDZ. Performed laboratory analysis: FDG, SF, GR, FC, WM. Analyzed the data: FDG, LDZ, GR. Drafted the manuscript: FDG. Critically revised the manuscript: FDG, RDA, GEA, GR, SG, LDZ. All the authors read and approved the final manuscript.

\section{Funding}

This work was supported by Addis Ababa University and Ghent University under the Special Research Fund (BOF) program for developing countries (Scholarship's code 01 W03916).

\section{Availability of data and materials}

All data generated during this study are included in the manuscript.

\section{Declarations}

Competing interests

All the authors state that they have no competing interests in this study.

\section{Author details}

${ }^{1}$ Department of Microbiology, Immunology and Veterinary Public Health, College of Veterinary Medicine and Agriculture, Addis Ababa University, P. O. Box 34, Bishoftu, Ethiopia. ${ }^{2}$ Department of Veterinary Public Health and Food Safety, Faculty of Veterinary Medicine, Ghent University, 9820 Merelbeke, Belgium. ${ }^{3}$ Department of Veterinary Biomedical Sciences, College of Veterinary Medicine, Long Island University, Greenvale, NY 11548, USA. ${ }^{4}$ U. S. Department of Agriculture, Agricultural Research Service, Food Animal Environmental Systems Research Unit, 2413 Nashville Road, B-5, Bowling Green, KY 42101, USA. ${ }^{5}$ Technology and Food Science Unit, Flanders Research Institute for Agriculture, Fisheries and Food, Melle, Belgium. ${ }^{6}$ Department of Human Bacterial Diseases, Sciensano, Brussels, Belgium. ${ }^{7}$ Department of Microbiology and Infection Control, Belgian National Reference Centre for STECNTEC, Vrije Universiteit Brussel (VUB), Universitair Ziekenhuis Brussel (UZ Brussel), Brussels, Belgium. ${ }^{8}$ Department of Nutrition, Genetics and Ethology, Faculty of Veterinary Medicine, Ghent University, Merelbeke, Belgium.

Received: 10 March 2021 Accepted: 28 May 2021

Published online: 04 July 2021

\section{References}

Abdissa R, Haile W, Fite AT, Beyi AF, Agga GE, Edao BM, Tadesse F, Korsa MG, Beyene T, Beyene TJ, De Zutter L, Cox E, Goddeeris BM (2017) Prevalence of Escherichia coli 0157: H7 in beef cattle at slaughter and beef carcasses at retail shops in Ethiopia. BMC Infect Dis 17:1-6. https://doi.org/10.1186/s12 879-017-2372-2

Arthur TM, Brichta-Harhay DM, Bosilevac JM, Kalchayanand N, Shackelford SD, Wheeler TL, Koohmaraie M (2010) Super shedding of Escherichia coli O157:H7 by cattle and the impact on beef carcass contamination. Meat Sci 70:10761079. https://doi.org/10.1016/j.meatsci.2010.04.019 
Atnafie B, Paulos D, Abera M, Tefera G, Hailu D, Kasaye S, Amenu K (2017) Occurrence of Escherichia coli 0157:H7 in cattle feces and contamination of carcass and various contact surfaces in abattoir and butcher shops of Hawassa, Ethiopia. BMC Microbiol 17:1-7. https://doi.org/10.1186/s12866-0170938-1

Atsbha TW, Weldeabezgi LT, Seyoum KA, Tafere G, Hailu KH (2018) Salmonella and risk factors for the contamination of cattle carcass from abattoir of Mekelle City, Ethiopia. Cogent Food Agric 4:1-8. https://doi.org/10.1 080/23311932.2018.1557313

Avery A (2014) Red meat and poultry production and consumption in Ethiopia and distribution in Addis Ababa. Borlaug-Ruan World Food Prize Intern. International Livestock Research Institute. 2004. https://cgspace.cgiar.org/ bitstream/handle/10568/35617/AbbeyAvery_2004.pdf?sequence=1. Accessed 22 Jan 2021

Bekele T, Zewde G, Tefera G, Feleke A, Zerom K (2014) Escherichia coli O157:H7 in raw meat in Addis Ababa, Ethiopia: prevalence at an abattoir and retailers and antimicrobial susceptibility. Int J Food Contam 1:1-8. https://doi.org/1 0.1186/s40550-014-0004-9

Brichta-Harhay DM, Guerini MN, Arthur TM, Bosilevac JM, Kalchayanand N, Shackelford SD, Wheeler TL, Koohmaraie M (2008) Salmonella and Escherichia coli 0157:H7 contamination on hides and carcasses of cull cattle presented for slaughter in the United States: an evaluation of prevalence and bacterial loads by immunomagnetic separation and direct plating methods. Appl Environ Microbiol 74:6289-6297. https://doi.org/10.1128/AEM.00700-08

CDC (2016) Centers for disease control and prevention. Multistate outbreak of Shiga toxin-producing Escherichia coli 0157: H7 infections linked to beef products. https://www.cdc.gov/ecoli/2016/0157h7-09-16/index.html. Accessed 1 Nov 2020

Cobbaut K, Houf K, Douidah L, Van Hende J, De Zutter L (2008) Alternative sampling to establish the Escherichia coli 0157 status on beef cattle farms. Vet Microbiol 132:205-210. https://doi.org/10.1016/j.vetmic.2008.04.031

Croxen MA, Law RJ, Scholz R, Keeney KM, Wlodarska M, Finlay BB (2013) Recent advances in understanding enteric pathogenic Escherichia coli. Clin Microbiol Rev 26:822-880. https://doi.org/10.1128/CMR.00022-13

Cummings KJ, Warnick LD, Elton M, Gröhn YT, McDonough PL, Siler JD (2010) The effect of clinical outbreaks of salmonellosis on the prevalence of fecal Salmonella shedding among dairy cattle in New York. Foodborne Pathog Dis 7:815-823. https://doi.org/10.1089/fpd.2009.0481

De Rauw K, Thiry D, Caljon B, Saulmont M, Mainil J, Piérard D (2019) Characteristics of Shiga toxin producing-and enteropathogenic Escherichia coli of the emerging serotype 080 : $\mathrm{H} 2$ isolated from humans and diarrhoeic calves in Belgium. Clin Microbiol Infect 25:111-115. https://doi.org/10.1016/j. cmi.2018.07.023

EFSA and ECDC (2018) The European Union summary report on trends and sources of zoonoses, zoonotic agents and food-borne outbreaks in 2017. EFSA J 16:1-262. https://doi.org/10.2903/j.efsa.2018.5500

EFSA and ECDC (2020) The European Union summary report on antimicrobial resistance in zoonotic and indicator bacteria from humans, animals and food in 2017/2018. EFSA J 18(3):1-166

Ejeta G, Molla B, Alemayehu D, Muckle CA (2004) Salmonella serotypes isolated from minced meat beef, mutton and pork in Addis Ababa, Ethiopia. Rev Med Vet 155:547-551

Essendoubi S, Stashko N, So I, Gensler G, Rolheiser D, Mainali C (2019) Prevalence of Shiga toxin-producing Escherichia coli (STEC) 0157:H7, six non-O157 STECs, and Salmonella on beef carcasses in provincially licensed abattoirs in Alberta, Canada. Food Control 105:226-232. https://doi.org/10.1016/j.foodcont.2019. 05.032

Grimont PP, Weill FF-X (2007) Antigenic formulae of the Salmonella Serovars. 9th edn, World Health Organization Collaborating Center for Reference and Research on Salmonella, Institut Pasteur, Paris

Gutema FD, Agga GE, Abdi RD, De Zutter L, Duchateau L, Gabriël S (2019) Prevalence and serotype diversity of Salmonella in apparently healthy cattle: systematic review and meta-analysis of published studies, 2000-2017. Front Vet Sci 6:1-11. https://doi.org/10.3389/fvets.2019.00102

Gutema FD, Geertrui R, Getahun EA, Olana M, Addisu BD, Reta DA, Luc D, Wesley M, Sarah G, Lieven DZ (2021c) Prevaelnce, molecular characteristics and antimicrobial resistance of Salmonella in cattle, beef and in diarrheic patients in Bishoftu town, Ethiopia. Foodborne Pathog Dis (18):283-289. https://doi. org/10.1089/fpd.2020.2869

Gutema FD, Getahun EA, Reta DA, Alemnesh J, Luc D, Lieven DZ, Sarah G (2021a) Assessment of hygienic practices in beef slaughterhouses and retail shops in
Bishoftu, Ethiopia: implication for public health. Int J Environ Health Public Health 18:1-13. https://doi.org/10.3390/ijerph18052729

Gutema FD, Rasschaert G, Agga GE, Jufare A, Duguma AB, Abdi RD, Duchateau L, Crombe F, Gabriël S, De Zutter L (2021b) Occurrence, molecular characteristics, and antimicrobial resistance of Escherichia coli 0157 in cattle, beef, and humans in Bishoftu Town, Central Ethiopia. Foodborne Pathog Dis 18:1-7. https://doi.org/10.1089/fpd.2020.2830

Gyles CL (2007) Shiga toxin-producing Escherichia coli: an overview1. J Anim Sci 85:45-62. https://doi.org/10.2527/jas.2006-508

Haile AF, Kebede D, Wubshet AK (2017) Prevalence and antibiogram of Escherichia coli 0157 isolated from bovine in Jimma, Ethiopia: abattoirbased survey. Ethiop Vet J 21:109-120. https://doi.org/10.4314/evj.v21i2.8

Harvey RR, Friedman CR, Crim SM, Judd M, Barrett KA, Tolar B, Folster JP, Griffin PM, Brown AC (2017) Epidemiology of Salmonella enterica serotype Dublin infections among humans, United States, 1968-2013. Emerg Infect 23:14931501

Havelaar AH, Kirk MD, Torgerson PR, Gibb HJ, Hald T, Lake RJ et al (2015) World health organization global estimates and regional comparisons of the burden of foodborne disease in 2010. PLoS Med 12:1-23. https://doi.org/1 0.1371/journal.pmed.1001923

Islam MZ, Musekiwa A, Islam K, Ahmed S, Chowdhury S, Ahad A, Biswas PK (2014) Regional variation in the prevalence of E. coli 0157 in cattle: a metaanalysis and meta-regression. PLoS One 9:1-15. https://doi.org/10.1371/ journal.pone.0093299

ISO (2001) ISO (International Organization for Standardization) 16654:2001. Microbiology of food and animal feeding stuffs — Horizontal method for the detection of Escherichia coli 0157. https://www.iso.org/standard/29821. html. Accessed 22 Dec 2020

ISO (2017) ISO. ISO 6579-1:2017. Microbiology of the food chain - horizontal method for the detection, enumeration and serotyping of Salmonella - Part 1: detection of Salmonella spp. https://www.iso.org/standard/56712.html. Accessed 22 Dec 2020

Madoroba E, Kapeta D, Gelaw AK (2016) Salmonella contamination, serovars and antimicrobial resistance profiles of cattle slaughtered in South Africa. Onderstepoort J Vet Res 83:1-8. https://doi.org/10.4102/ojvr.v83i1.1109

Mattheus W, Ceyssens P., Van Den Bossche A, Bertrand S, Mathys V (2018) Nationaal referetiecentrum Salmonella and Shigella (unpublished)

Muluneh G, Kibret M (2015) Salmonella spp. and risk factors for the contamination of slaughtered cattle carcass from a slaughterhouse of Bahir Dar Town, Ethiopia. Asian Pac J Trop Dis 5:130-135. https://doi.org/10.1016/ S2222-1808(14)60640-X

Pires SM, Majowicz S, Gill A, Devleesschauwer B (2019) Global and regional source attribution of Shiga toxin-producing Escherichia coli infections using analysis of outbreak surveillance data. Epidemiol Infect 147:1-9. https://doi. org/10.1017/S095026881900116X

Plumb ID, Schwensohn CA, Gieraltowski L, Tecle S, Schneider ZD, Freiman J, Cote A, Noveroske D, Kolsin J, Brandenburg J, Chen JC, Tagg KA, White PB, Shah HJ, Francois Watkins LK, Wise ME, Friedman CR (2019) Outbreak of Salmonella Newport infections with decreased susceptibility to azithromycin linked to beef obtained in the United States and soft cheese obtained in Mexico United States, 2018-2019. MMWR Morb Mortal Wkly Rep 68:713-717. https:// doi.org/10.15585/mmwr.mm6833a1

Rasschaert G, Houf K, Imberechts H, Grijspeerdt K, De Zutter L, Heyndrickx M (2005) Comparison of five repetitive-sequence-based PCR typing methods for molecular discrimination of Salmonella enterica isolates. J Clin Microbiol 43: 3615-3623. https://doi.org/10.1128/JCM.43.8.3615-3623.2005

Reid CA, Small A, Avery SM, Buncic S (2002) Presence of food-borne pathogens on cattle hides. Food Control 13:411-415. https://doi.org/10.1016/S0956-713 5(01)00050-0

Rhoades JR, Duffy G, Koutsoumanis K (2009) Prevalence and concentration of verocytotoxigenic Escherichia coli, Salmonella enterica and Listeria monocytogenes in the beef production chain: a review. Food Microbiol 26: 357-376. https://doi.org/10.1016/j.fm.2008.10.012

Seleshe S, Jo C, Lee M (2014) Meat consumption culture in Ethiopia. Korean J Food Sci Anim Resour 34:7-13. https://doi.org/10.5851/kosfa.2 014.34.1.7

Sibhat B, Molla Zewde B, Zerihun A, Muckle A, Cole L, Boerlin P, Wilkie E, Perets A, Mistry K, Gebreyes WA (2011) Salmonella serovars and antimicrobial resistance profiles in beef cattle, slaughterhouse personnel and slaughterhouse environment in Ethiopia. Zoonoses Public Health 58:102-109. https://doi.org/10.1111/j.1863-2378.2009.01305.x 
Tadesse G (2014) Prevalence of human salmonellosis in Ethiopia: a systematic review and meta-analysis. BMC Infect Dis 14:1-10. https://doi.org/10.1186/14 71-2334-14-88

Tadesse G, Tessema TS (2014) A meta-analysis of the prevalence of Salmonella in food animals in Ethiopia. BMC Microbiol 14:1-9. https://doi.org/10.1186/s12 866-014-0270-y

Takele S, Woldemichael K, Gashaw M, Tassew H, Yohannes M, Abdissa A (2018) Prevalence and drug susceptibility pattern of Salmonella isolates from apparently healthy slaughter cattle and personnel working at the Jimma municipal abattoir, south-West Ethiopia 11 medical and health sciences 1108 medical microbiology 11 medical and H. Trop Dis Travel Med Vaccines 4:1-7. https://doi.org/10.1186/s40794-018-0072-6

Thomas KM, de Glanville WA, Barker GC, Benschop J, Buza JJ, Cleaveland S, Davis MA, French NP, Mmbaga BT, Prinsen G, Swai ES, Zadoks RN, Crump JA (2020) Prevalence of campylobacter and Salmonella in African food animals and meat: a systematic review and meta-analysis. Int J Food Microbiol 315:1-22. https://doi.org/10.1016/j.jifoodmicro.2019.108382

Wabeto W, Abraham Y, Anjulo AA (2017) Detection and identification of antimicrobial-resistant Salmonella in raw beef at Wolaita Sodo municipal abattoir, southern Ethiopia. J Health Popul Nutr 36:1-7. https://doi.org/10.11 86/s41043-017-0131-z

\section{Publisher's Note}

Springer Nature remains neutral with regard to jurisdictional claims in published maps and institutional affiliations.

Ready to submit your research? Choose BMC and benefit from:

- fast, convenient online submission

- thorough peer review by experienced researchers in your field

- rapid publication on acceptance

- support for research data, including large and complex data types

- gold Open Access which fosters wider collaboration and increased citations

- maximum visibility for your research: over $100 \mathrm{M}$ website views per year

At $\mathrm{BMC}$, research is always in progress.

Learn more biomedcentral.com/submissions 